HOEHNE, L; ALTMAYER, T; MARTINI, MC; FINATTO, J; BRIETZKE, DT; KUHN, D; SCHWEIZER, YA; VETTORELLO, G; CORDEIRO, SG; ETHUR, EM; FREITAS, EM; SEVERO FILHO, WA. 2020. Effect of humus and soil substrates on production parameters and quality of organic strawberries. Horticultura Brasileira 38: 101-106. DOI - http://dx.doi.org/10.1590/S0102-053620200116

\title{
Effect of humus and soil substrates on production parameters and quality of organic strawberries
}

\author{
Lucélia Hoehne ${ }^{1} \mathbb{D} ;$ Taciélen Altmayer ${ }^{1} \mathbb{D} ;$ Maira C Martini ${ }^{1} \mathbb{D} ;$ Jordana Finatto ${ }^{1} \mathbb{D} ;$ Débora T Brietzke ${ }^{1} \mathbb{D} ;$ Daniel \\ Kuhn ${ }^{1} \mathbb{D}$; Ytan A Schweizer ${ }^{1} \mathbb{D}$; Gabriela Vettorello ${ }^{1} \mathbb{D}$; Sabrina G Cordeiro ${ }^{1} \mathbb{D}$; Eduardo M Ethur ${ }^{1} \mathbb{D}$; Elisete $M$ \\ de Freitas ${ }^{1} \mathbb{D}$; Wolmar A Severo Filho ${ }^{2} \mathbb{D}$
}

\begin{abstract}
'Universidade do Vale do Taquari (UNIVATES), Lajeado-RS, Brasil; luceliah@univates.br; tacielen95@hotmail.com; mairinha.martini@ hotmail.com; jordanafinatto@universo.univates.br; dbrietzke@universo.univates.br; danielkuhn@universo.univates.br; ytan.schweizer@ universo.univates.br; gvettorello@universo.univates.br; sabrina.cordeiro@universo.univates.br; eduardome@univates.br; elicauf@univates. br; ${ }^{2}$ Universidade de Santa Cruz do Sul (UNISC), Santa Cruz do Sul-RS, Brasil; wolmar@unisc.br
\end{abstract}

\begin{abstract}
This study aims to verify the most suitable substrate formulation based on proportions of earthworm humus and soil to improve the quality of organic strawberries. Vermicomposting generated humus and strawberry seedlings were planted in different humus:soil ratios: (0:100; 20:80; 40:60; 60:40; 80:20 and 100:0, respectively). The proportional conditions were characterized after planting and after 60 day cultivation, plants were harvested, and chemical characterizations of the soil and plants were made. We verified that with an increase of humus content in the substrate, an increase in values of $\mathrm{N}, \mathrm{P}, \mathrm{K}, \mathrm{pH}$ and organic matter in soil and dry and fresh mass in shoot area of the plants were noticed. In relation to fruits, $\mathrm{pH}$, humidity and sodium concentration, the authors noticed no change under any conditions and ash content was lower when an increase of humus in soil was observed. Higher values of potassium and protein occurred from 40:60 and 60:40, respectively. Higher values for average strawberry production were verified from 60:40 condition. Reducing sugars and titratable acidity increased and stabilized at 20:80 and 60:40, respectively. Thus, in order to avoid excess of nutrients in the substrate, which can hinder plant growth, humus condition in the ratio 60:40 humus:soil is recommended for higher values of production, nutrients and protein in strawberry cultivation.
\end{abstract}

Keywords: Fragaria x ananassa, húmus, fertilizer, nutrients.

\section{RESUMO}

Efeito de substratos feitos de húmus e solo sobre parâmetros de produção e qualidade do morango orgânico

O objetivo desse estudo foi verificar a formulação mais adequada de um substrato baseado em proporções de húmus de minhoca e solo para melhorar a qualidade de morango orgânico. Para isso, foi gerado o húmus através da vermicompostagem e feito o plantio de mudas de morangueiros em diferentes proporções de húmus:solo (0:100; 20:80; 40:60; 60:40; 80:20 e 100:0, respectivamente). As condições de proporções foram caracterizadas, feito o plantio e após 60 dias de cultivo, as plantas foram colhidas, e feitas as caracterizações químicas do solo e das plantas. Como resultados, pode-se verificar que, com o aumento do teor de húmus no substrato, houve aumento nos valores de N, P, K, pH e matéria orgânica no solo e massa seca e fresca na parte aérea das plantas. Em relação aos frutos, $\mathrm{pH}$, umidade e concentração de sódio não alteraram em nenhuma condição e o teor de cinzas foi menor quando houve aumento de húmus no solo. Para os parâmetros de maiores valores de potássio e de proteína ocorreram a partir de 40:60 e 60:40, respectivamente. Já para a produção média de morangos teve valores maiores a partir da condição 60:40. Açúcares redutores e acidez titulável aumentaram e estabilizaram nas condições de 20:80 e 60:40, respectivamente. Dessa forma, para evitar excesso de nutrientes contidos no substrato, que pode prejudicar o crescimento das plantas, indica-se a condição de 60:40 de húmus:solo para maiores valores de produção, nutrientes e proteína no cultivo de morangos.

Palavras-chaves: Fragaria x ananassa, húmus, fertilizante, nutrientes.

\section{Received on June 12, 2019; accepted on February 18, 2020}

$\mathrm{S}_{\mathrm{b}}^{\mathrm{t}}$ rawberry (Fragaria $\mathrm{x}$ ananassa) is botanically classified as a vegetable belonging to Rosaceae family, genus Fragaria. The edible part consists of a fleshy and juicy receptacle, bright red color, being a pseudofruit. The real fruits (the achenes) are tiny structures, which contain the seeds and are attached to the receptacle. It is a typical mildclimate crop and little tolerant to high temperatures (Cronquist, 1988). It is one of the most commonly consumed berries worldwide due to its beneficial nutritional properties (Gianpieri et al., 2014). In Brazil, strawberry is produced in small properties and an increasing tendency exists in area and production improvement studies (Ritcher et al., 2018). Strawberry is grown commercially in several states,
Rio Grande do Sul is one of the most important Brazilian producers (Antunes et al., 2010; Eckert et al., 2015; Zeist \& Resende, 2019).

Strawberry needs available nutrients in substrate in order to promote its development to produce fruits with suitable nutritional properties. When a nutrient is deficient, the plant expresses this imbalance by visual symptoms 
which are manifested mainly through changes in the leaves, such as color, size and others, since this is the organ of the plant in full physiological and chemical activity (Gonçalves et al., 2006).

In order to obtain better nutritional and biological soil quality, the complementation with earthworm humus can be quite positive, since besides being essential nutrients for plants, it increases the microbial load, providing greater plant growth and improving soil quality (Domínguez et al., 2010; Silva et al., 2010; Lim et al., 2014).

Thus, vermicomposting (humus) is an accelerated process of biooxidation and stabilization of organic waste which involves interactions between earthworms and microorganisms (Domínguez, 2004). The process improves the physical, chemical and biological characteristics of the compound and, consequently, improves its acceptance and commercial value (Conti et al., 2014; Blouin et al., 2019)

Humus has higher contents of nitrogen $(\mathrm{N})$, phosphorus (P) and potassium (K) (Cotta et al., 2015), accelerating the growth process of plants cultivated on substrates which contain this compound in the soil (Sinha et al., 2010; Rekasi et al, 2019). It should be noted that an extreme humus condition in a strawberry crop can also be harmful to the plant presenting toxicity due to the high content of mineral salts present in the substrate, as already described in some studies (Altieri et al., 2010, 2014).

In this sense, in order to help out organic strawberry producers of small rural properties to use its own domestic residues, for a sustainable agriculture, we aimed to verify the most suitable proportion for a humus substrate and soil to obtain better productivity and nutritional quality of strawberries.

\section{MATERIAL AND METHODS}

The humus generated in this study was produced in the Laboratory of Biotecnology, of Tecnovates, at Universidade in Vale do Taquari (UNIVATES), in Lajeado-RS. Household organic waste, such as fruit peels, vegetable scraps, coffee grounds, among others, and Eisenia andrei worm species (known as California Red Worm) were used. We have used a vertical system in plastic boxes (46 L) for 60 days. Then, the humus was homogenized and added to the soil collected at UNIVATES. Afterwards, it was mixed in a soil in the rates of $0: 100 ; 20: 80 ; 40: 60 ; 60: 40 ; 80: 20$ and 100:0 humus:soil masses. Samples of each ratio were sent to Laboratório de Análises de Solos of Universidade de Santa Cruz do Sul, in Santa Cruz do Sul-RS, for chemical characterization, using the methodology according to EMBRAPA (2017).

The research was carried out in a greenhouse of UNIVATES $\left(29^{\circ} 45^{\prime} \mathrm{S}\right.$, $51^{\circ} 94^{\prime} \mathrm{W}$ ), temperature and relative humidity were monitored from July to December, 2018. Each treatment consisted of 25 seedlings in each pot, totalizing 150 seedlings of cultivar Camarosa (national seedling obtained in the local market). The experimental design was randomized blocks with six treatments and four replicates. Seedlings were planted individually in 250 -g polyethylene pots, specific for this cultivation, spacing $35 \mathrm{~cm}$ between each pot.

After a 60-day cultivation, all plants were collected during two weeks, when the fruits were ripe. We counted the shoot area of all plants of each treatment (leaves, petioles and stolons) and weighed to obtain fresh mass. Then, shoots were placed in oven with forced air circulation at $60^{\circ} \mathrm{C}$ temperature to obtain dry mass until constant weight.

Fruits were harvested, washed and counted in order to analyze the production in each treatment. For the other evaluated parameters, we randomly collected 25 fruits of 25 plants. We used a blender to make an homogeneous mixture, and this mass was used to analyze $\mathrm{pH}$, ashes, humidity, mineral nutrients ( $\mathrm{K}$ and $\mathrm{Na}$ ), protein, reducing sugars and titratable acidity (Lutz, 2008; Santos et al., 2011; Rufino et al., 2007). The other fruits were frozen just in case of repeating any analyses. Fruit $\mathrm{pH}$ was measured with the aid of a digital bench pHmeter following the methodology described by Lutz (2008). To determine ashes in fruits, 5 g homogenized mixture were weighed in a porcelain crucible. Afterwards, the fruits were placed in a muffle furnace at $550^{\circ} \mathrm{C}$ for $5 \mathrm{~h}$ (Lutz, 2008).

To quantify humidity content in strawberries, $5 \mathrm{~g}$ of the mixture were weighed in each treatment in a porcelain capsule. Then, samples were put in

Table 1. Chemical and physical parameters evaluated in strawberry fruits in different ratios of vermicompost. About 25 fruits randomly set of 25 plants in each trial. Lajeado, UNIVATES, 2018-2019.

\begin{tabular}{lcccccc}
\hline $\begin{array}{l}\text { Conditions } \\
\text { (humus:soil) }\end{array}$ & $\mathbf{0 : 1 0 0}$ & $\mathbf{2 0 : 8 0}$ & $\mathbf{4 0 : 6 0}$ & $\mathbf{6 0 : 4 0}$ & $\mathbf{8 0 : 2 0}$ & $\mathbf{1 0 0 : 0}$ \\
\hline $\mathrm{pH}$ & $3.95 \pm 0.49 \mathrm{a}$ & $3.61 \pm 0.32 \mathrm{a}$ & $3.59 \pm 0.34 \mathrm{a}$ & $3.78 \pm 0.43 \mathrm{a}$ & $3.80 \pm 0.28 \mathrm{a}$ & $3.87 \pm 0.29 \mathrm{a}$ \\
Humidity (\%) & $92 \pm 5 \mathrm{a}$ & $91 \pm 3 \mathrm{a}$ & $92 \pm 4 \mathrm{a}$ & $92 \pm 4 \mathrm{a}$ & $91 \pm 5 \mathrm{a}$ & $92 \pm 4 \mathrm{a}$ \\
Ashes (\%) & $0.45 \pm 0.16 \mathrm{a}$ & $0.46 \pm 0.09 \mathrm{a}$ & $0.34 \pm 0.02 \mathrm{~b}$ & $0.32 \pm 0.02 \mathrm{~b}$ & $0.36 \pm 0.04 \mathrm{~b}$ & $0.29 \pm 0.03 \mathrm{c}$ \\
Protein (\%) & $0.35 \pm 0.02 \mathrm{c}$ & $0.42 \pm 0.02 \mathrm{~b}$ & $0.41 \pm 0.03 \mathrm{~b}$ & $0.50 \pm 0.04 \mathrm{a}$ & $0.53 \pm 0.05 \mathrm{a}$ & $0.53 \pm 0.02 \mathrm{a}$ \\
Potassium (\%) & $4.70 \pm 0.79 \mathrm{~b}$ & $7.26 \pm 0.79 \mathrm{a}$ & $6.12 \pm 1.14 \mathrm{a}$ & $7.04 \pm 1.04 \mathrm{a}$ & $7.49 \pm 0.70 \mathrm{a}$ & $6.33 \pm 0.69 \mathrm{a}$ \\
Sodium (\%) & $0.90 \pm 0.07 \mathrm{a}$ & $0.95 \pm 0.18 \mathrm{a}$ & $0.84 \pm 0.11 \mathrm{a}$ & $0.99 \pm 0.39 \mathrm{a}$ & $0.89 \pm 0.22 \mathrm{a}$ & $1.13 \pm 0.31 \mathrm{a}$ \\
\hline
\end{tabular}

Content $\%$ expressed in $\mathrm{m} / \mathrm{m}$. Different letters in the line mean statistical difference. 
an oven at $105^{\circ} \mathrm{C}$, until constant mass (Lutz, 2008).

To determine protein, we used the Kjeldahl method according to Lutz (2008), using digestion with sulfuric acid and phosphorus pentoxide and subsequent use of potassium permanganate. Mineral nutrients in fruits were determined using the ashes. The fruits were then heated and 1:1 hydrochloric acid and ultra pure water were added to samples. After that, samples were filtered and measured in a 100-mL volumetric flask (Lutz, 2008). The authors determined $\mathrm{K}$ and $\mathrm{Na}$ using a flame photometer (Digimed DM-62).

To determine the content of glucosereducing sugars, according to Lutz (2008), Fehling A and B solutions were used and titrated with a solution obtained from the strawberry samples.

Titratable acidity was determined using potentiometric volumetry. Titration was done with $0.1 \mathrm{M}$ sodium hydroxide, using a pHmeter to control the titration, until $\mathrm{pH}$ reached between 8.2 and 8.4 (Lutz, 2008).

Data obtained from the analyses of $\mathrm{pH}$, ashes, proteins and nutrients ( $\mathrm{Na}$ and $\mathrm{K})$ in the six treatments were submitted to the variance analysis (ANOVA) at $5 \%$ probability, using Bioestat statistical software. To calculate soil, dry mass, fresh mass and fruit production, data were submitted to regression analysis using Winstat, version 2.0 statistical software. The experimental design consisted of randomized blocks, 25 plants in each trial, with four replicates.

\section{RESULTS AND DISCUSSION}

The results of chemical characterization of the different treatments, in relation to contents of $\mathrm{N}, \mathrm{P}$ and $\mathrm{K}$ are presented in Figure 1a, values of $\mathrm{pH}$ in Figure $1 \mathrm{~b}$ and organic matter content in Figure 1c. We verified that the greater quantity of humus added to the substrate, the higher were the levels of N, P and $\mathrm{K}$. The authors also verified an increase in substrate $\mathrm{pH}$ and organic matter, probably in relation to biotransformation of waste into organic substances. These results are in accordance with Hoehne et al. (2016), showing greater concentration of these elements in greater contents of humus. According to Kiehl (1985), the nutrients from humus are more bioavailable for plants grown in this environment, which may favor better development and production.

In Figure 2 are presented values of strawberry shoot fresh and dry masses
(Figure 2a) and strawberry production (Figure 2b) (overall average of each treatment, $\mathrm{n}=25$ ).

Adding vermicompost to the substrate increased the fresh and dry masses of the strawberry. These parameters are directly related to vegetative development of the plant, since the larger the leaf area of the crop,

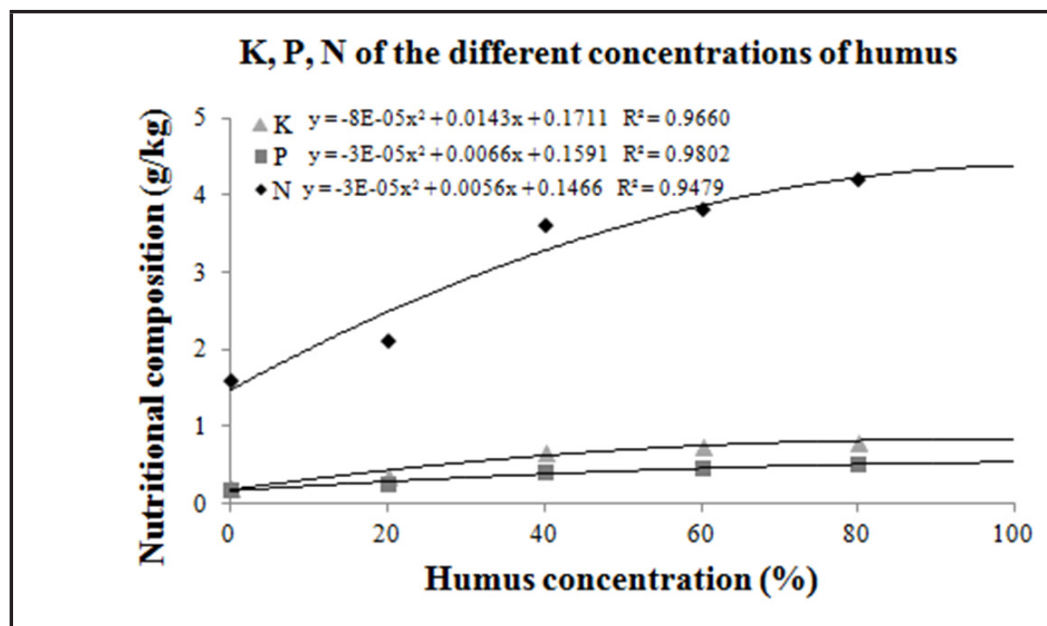

\section{pH of soil depending on differente humus concentrations}
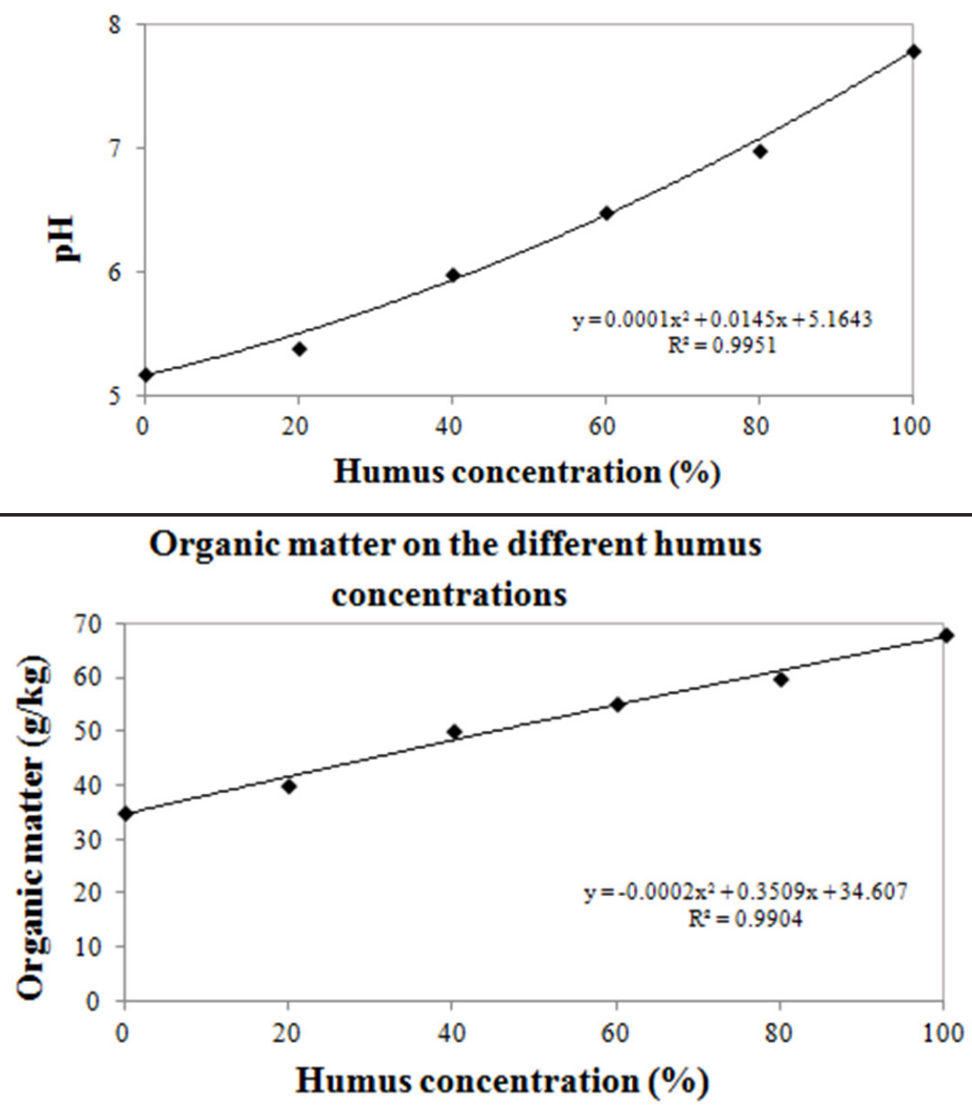

Figure 1. Chemical characterization of different humus and soil ratios. Lajeado, UNIVATES, 2018-2019. 
the greater the amount of assimilates produced and stored, thus improving the photosynthetic area of the plant and consequently the fruit production (Taiz $\&$ Zeiger, 2009). The average number of fruits per plant was calculated (15day harvest): the authors observed a production stabilization from 60:40 ratio. We also visually observed the most reddish color and greater size of fruits from this condition. This fact was probably due to the humus used in this study already contained sufficient $\mathrm{N}, \mathrm{P}$ and $\mathrm{K}$ for this plant (Cotta et al., 2015). These mineral nutrients probably raise strawberry productivity. These values are in accordance with Oliveira et al. (2011), who evaluated the maximum production of strawberry cultivar Camarosa considering the 15day harvest carried out in this study, both for productivity and fresh mass.

Considering the data shown in Table 1 , no significant difference in $\mathrm{pH}$ values among treatments was noticed; this fact points out that the humus content in the substrate did not alter fruit $\mathrm{pH}$. According to Conti et al. (2002), fruit $\mathrm{pH}$ is within an appropriate range (around 3.7), verified in studies carried out with five strawberry cultivars.

In relation to ash contents, we found $0.45 \%(\mathrm{~m} / \mathrm{m})$ in the experiment without humus $(0: 100)$ and $0.29 \%$ of ashes for substrates with 100:0 humus. These results are similar to the ones described in Brazilian Table of Food Composition published by State University of Campinas (Unicamp) (2011). It means that the higher the organic matter concentration, the smaller the amount of ash present in the fruit, since humus presents more organic components which can easily be absorbed by the plants.
In relation to protein values (Table 1), as the humus content in the substrate increased, this parameter increased to a ratio of 60:40 humus and soil. Using this condition, no statistic difference in the results for other ratios with higher humus content was noticed. This may be related with $\mathrm{N}$ content, which may be more bioavailable in humus from that condition (Kiehl, 1985; Cotta et al., 2015). Both results showed values similar to the ones described by other authors (Unicamp, 2011; Unifesp, 2015). In relation to humidity, no significant difference among the results was noticed, showing that different ratios of humus and soil did not influence this parameter. In Table 1, we verified that $\mathrm{K}$ contents increased when 20:80 of humus and soil was tested. This probably

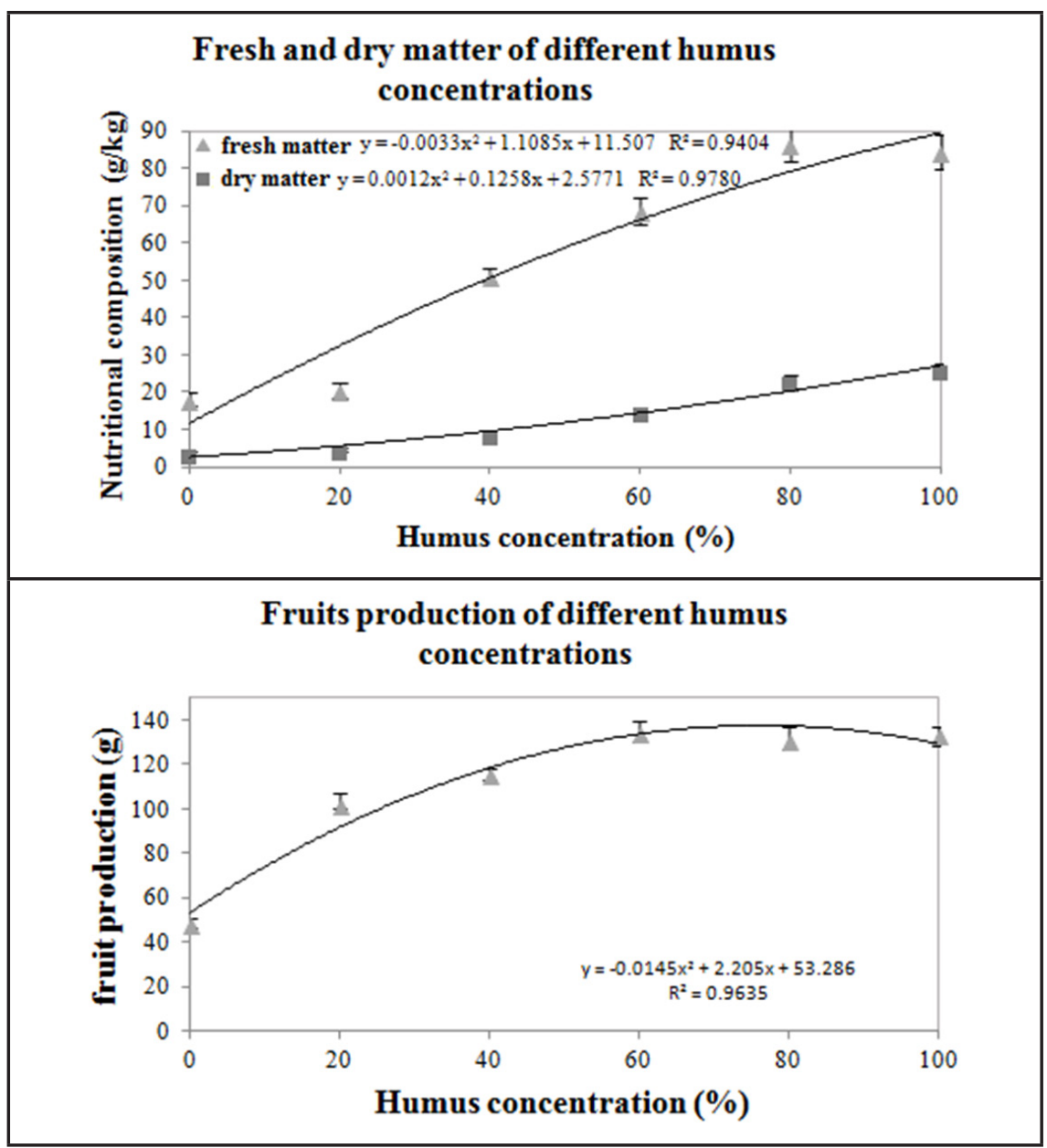

Figure 2. Strawberry shoot fresh and dry masses and strawberry productivity grown in different ratios of earthworm humus. Each trial consists of about 25 plants. Lajeado, UNIVATES, 2018-2019.

Table 2. Contents of sugars and titratable acidity evaluated in fruits in different ratios of earthworm humus. Each trial consists of 25 plants. Lajeado, UNIVATES, 2018-2019.

\begin{tabular}{lcccccc}
\hline $\begin{array}{l}\text { Condition } \\
\text { (humus:soil) }\end{array}$ & $\mathbf{0 : 1 0 0}$ & $\mathbf{2 0 : 8 0}$ & $\mathbf{4 0 : 6 0}$ & $\mathbf{6 0 : 4 0}$ & $\mathbf{8 0 : 2 0}$ & $\mathbf{1 0 0 : 0}$ \\
\hline $\begin{array}{l}\text { Reducing sugars } \\
(\mathrm{mg} / 100 \mathrm{~g})\end{array}$ & $2.41 \pm 0.09 \mathrm{~b}$ & $3.55 \pm 0.29 \mathrm{a}$ & $3.23 \pm 0.11 \mathrm{a}$ & $3.16 \pm 0.06 \mathrm{a}$ & $3.39 \pm 0.64 \mathrm{a}$ & $3.62 \pm 0.59 \mathrm{a}$ \\
$\begin{array}{l}\text { Titratable acidity } \\
(\mathrm{mg} / 100 \mathrm{~g})\end{array}$ & $1.52 \pm 0.03 \mathrm{c}$ & $2.03 \pm 0.04 \mathrm{~b}$ & $1.92 \pm 0.07 \mathrm{~b}$ & $2.11 \pm 0.02 \mathrm{a}$ & $2.05 \pm 0.05 \mathrm{a}$ & $2.07 \pm 0.06 \mathrm{a}$ \\
\hline
\end{tabular}

Different letters in the line mean statistical difference. 
happened due to the presence of $\mathrm{K}$ bioavailable in this humus (Adu et al., 2018). Sodium content was not altered in any evaluated ratios and values were close to $1 \%$, corroborating other studies (Unicamp, 2011; Unifesp, 2015). The authors highlighted that the excess of salts can hinder the development of most plants (Zhang et al., 2015).

Table 2 shows contents of sugars and titratable acidity obtained in analysis of strawberry fruit. According to Camargo et al. (2009), the reducing sugars of cultivar Camarosa were $4.87 \%$, whereas in Guimarães et al. (2013), reducing sugar content of this cultivar was $1.81 \%$. We verified that the results in this study are similar to the ones cited above. Different values in relation to different interactions between cultivars and environment is common (Darolt, 2008). The same way, titratable acidity contents may also vary according to interactions with substrates. According to Françoso et al. (2008), values of total titratable acidity varied from 1.14 to $1.68 \mathrm{mg} / 100$ g. In this study, the values were superior (from 1.52 to $2.11 \mathrm{mg} / 100 \mathrm{~g}$ ).

Based on the abovementioned results, we suggest, for a greater strawberry production, ratios from 60:40 of humus and soil, respectively. Furthermore, from this condition, higher protein content in the fruits can be noticed. Moreover, this study is able to help out rural producers to reuse organic waste in their crops, highlighting parameters which can be improved, adding higher quality to the fruits.

\section{ACKNOWLEDGEMENTS}

The authors thank to Coordination of Improvement of Higher Education Personnel (CAPES), financial code 001, to UNIVATES for scholarship granted and financial resources for this project development and to Peterson Haas for helping out on the performance of the regression analyses.

\section{REFERENCES}

ADU, MO; ASARE, PA; YAWSON, DO; NYARKO, MA; OSEI-AGYEMAN K.
2018. Agronomic biofortification of selected underutilised solanaceae vegetables for improved dietary intake of potassium (K) in Ghana. Heliyion: Elsevier 4: 1-30.

ALTIERI, R.; ESPOSITO, A.; BARUZZI, G. 2010. Use of olive mill waste mix as peat surrogate in substrate for strawberry soilless cultivation. International Biodeterioration \& Biodegradation 64: 670-675.

ALTIERI, R; ESPOSITO, A; BARUZZI, G; NAIR, T. 2014. Corroboration for the successful application of humified olive mill waste compost in soilless cultivation of strawberry. International Biodeterioration \& Biodegradation 68: 118-124.

ANTUNES, LEC; RISTOW, NC; KROLOW, ACR; CARPENEDO, S; JUNIOR, CR. 2010. Yield and quality of strawberry cultivars. Horticultura Brasileira 28: 222-226.

BLOUIN, M; BARRERE, J; MEYER, N; LARTIGUE, S; BAROT, S; MATHIEU, J. 2019. Vermicompost significantly affects plant growth. A meta-analysis. Agronomy for Sustainable Development 39: 34.

CAMARGO, LKP; RESENDE, JTV; GALVÃO, AG; BAIER, JE; FARIA, MV; CAMARGO, CK. 2009. Caracterização química de frutos de morangueiro cultivados em vasos sob sistemas de manejo orgânico e convencional. Semina: Ciências Agrárias 30: 993-998.

CONTI, JH; MINAMI, K; TAVARES, FCA. 2002. Produção e qualidade de frutos de diferentes cultivares de morangueiro em ensaios conduzidos em Atibaia e Piracicaba. Horticultura Brasileira 20: 10-17.

CONTI, S; VILLARI, G; FAUGNO, S; MELCHIONNA J; SOMMA, S; CARUSO, G. 2014. Effects of organic vs. conventional farming system on yield and quality of strawberry grown as an annual or biennial crop in southern Italy. Scientia Horticulturae, 180: 63-71.

COTTA, JAO; CARVALHO, NLC; BRUM, TS; REZENDE, MOO. 2015. Compostagem versus vermicompostagem: comparação das técnicas utilizando resíduos vegetais, esterco bovino e serragem. Engenharia Ambiental e Sanitária 20: 65-78.

CRONQUIST, A. 1988. The evolution and classification of flowering plants. Bronx: The New York Botanical Garden. 555p.

DARLOT, MR. 2008. Morango orgânico: opção sustentável para o setor. Revista Campo e Negócios Ano II: 58-61.

DOMÍNGUEZ, J. 2004. State of the art and new perspectives on vermicomposting research. P. 401-424. In: EDWARDS CA (ed). Earthworm Ecology, $2^{\text {nd }}$ ed. Boca Raton: CRC Press.

DOMINGUEZ, J; LASCANO, C; GÓMESBRANDON, M. 2010. Influencia del vermicompost en el crecimiento de las plantas. Aportes para la elaboración de un concepto objetivo. Acta Zoologica Mexicana 26: 359-371.

ECKERT. A; BIASIO. R; MECCA. MS; DANI, D. 2015. Determinação do custo e da rentabilidade na cultura do morango em uma pequena propriedade agrícola situada no município de Flores da Cunha-RS. Custos e agronegócio on line, 11, 2015. Available at <uni://www.custoseagronegocioonline. com.br/numero1v11/OK_10_morango.pdf> Accessed May 29, 2019.

EMBRAPA, 2017. Manual de métodos de análise de solo / Paulo César Teixeira et al. editores técnicos. 3.ed. rev. e ampl. Brasília-DF.

FRANÇOSO, ILT; COUTO, MAL; CANNIATTIBRAZACA, SG; ARTHUR, V. 2008. Alterações físico-químicas em morangos (Fragaria anassa Duch.) irradiados e armazenados. Ciência e Tecnologia dos Alimentos 28: 614-619.

GIAMPIERI, F; ALVAREZ-SUAREZ, JM; BATTINO, M. 2014. Strawberry and human health effects beyond antioxidant activity. Journal of Agricultural and Food Chemistry 18: 3867-3876.

GONÇALVES, FC; NEVES, OSC; CARVALHO, JG. 2006. Deficiência nutricional em mudas de umbuzeiro decorrente da omissão de macronutrientes. Pesquisa Agropecuária Brasileira 41: 1053-1057.

GUIMARÃES, AG; VIEIRA, G; BATISTA, AG; PINTO, NAVD; VIANA, DJS. 2013. Características físico-químicas e antioxidantes de cultivares de morangueiro no Vale do Jequitinhonha. Tecnologia \& Ciência Agropecuária 7: 35-40.

HOEHNE, L; LIMA, CVS; MARTINI, MC; ALTMAYER, T; BRIETZKE, DT; FINATTO, J; GONÇALVES, TE; GRANADA, CE. 2016. Addition of vermicompost to heavy metal-contaminated soil increases the ability of black oat (Avena strigosa Schreb) plants to remove $\mathrm{Cd}, \mathrm{Cr}$, and $\mathrm{Pb}$. Water, Air \& Soil Pollution 227: 443.

KIEHL, EJ. 1985. Fertilizantes orgânicos. Piracicaba: Agronômica Ceres. 492p.

LIM, SL; WU, TY; LIM, PN; SHAK, KPY. 2014. The use of vermicompost in organic farming: Overview, effects on soil and economics. Journal of the Science of Food and Agriculture, p.n/a-n/a.

LUTZ, A. 2008. Métodos Físico-Químicos para Análise de Alimentos, $4^{\mathrm{a}}$ ed., Instituto Adolfo Lutz. Available at: <uni://www.crq4.org.br/ sms/files/file/analisedealimentosial_2008.pdf> Accessed October 20, 2019.

OLIVEIRA, RP; SCIVITTARO, WB; ROCHA, PSG. 2011. Produção de cultivares de morango, utilizando túnel baixo em Pelotas. Ceres 58: 625-631.

RÉKÁSI, M;. MAZSU, N; DRASKOVITS, E; BERNHARDT, B; SZABÓ, A; RIVIER, PA; CSILLA, F; BORSÁNYI, B; PIRKÓ, B; MOLNÁR, S; KÁTAY, G; UZINGER, N. 2019. Comparing the agrochemical properties of compost and vermicomposts produced from municipal sewage sludge digestate. Bioresource Technology 291: 1218612.

RICHTER, AF; FAGUERAZZI, AF; ZANIN, DS; SILVA, S; ARRUDA, AL; KRETZSCHMAR, AA; RUFATO, L. 2018. Produtividade e qualidade de cultivares de morangueiro sob cultivo de solo e semi-hidropônico. Científica Rural 20: 193-203.

RUFINO, MSM; ALVES, RE; BRITO, ES; MORAIS, SM; SAMPAIO, CG; PÉREZJIMÉNES, J; SAURA-CALIXTO. FD. 2007. Metodologia científica: determinação da 
atividade antioxidante total em frutas pela captura do radical livre DPPH. Comunicado Técnico 127: 1-4. Available at <http://www. cnpat.embrapa.br/cnpat/down/index.php?pub/ Cot_127> Accessed May 29, 2019.

SANTOS, SN; CASTANHA, RF; HABER, LL; MARQUES, MOM; SCRAMIM, S; MELO, IS. 2011. Determinação quantitativa da atividade antioxidante de extratos brutos de microrganismos pelo método de captura de radical livre DPPH. Comunicado Técnico 50: 1-5. Available at $<$ http://www.cnpma.embrapa. br/download/comunicado 50.pdf $>$ Accessed May 29, 2019.

SILVA, PRD; LANDGRAF, MD; ZOZOLOTTO,
TC; REZENDE, MOO. 2010. Estudo preliminar do vermicomposto produzido a partir de lodo de esgoto doméstico e solo. Eclética Química 35: 61:65.

SINHA, RK; VALANI, D.; CHAUHAN, K; AGARWAL, S. 2010. Embarking on a second green revolution for sustainable agriculture by vermiculture biotechnology using earthworms: Reviving the dreams of Sir Charles Darwin. Journal of Agricultural Biotechnology and Sustainable Development 2: 113-128.

TAIZ, L; ZEIGER, E. 2009. Fisiologia Vegetal, $4^{\mathrm{a}}$. ed. Porto Alegre: Artmed.

UNICAMP. Tabela brasileira de composição de alimentos - TACO $-2^{\mathrm{a}}$.ed. Universidade
Estadual de Campinas. 2011. 164p.

UNIFESP. Relatório básico: morango cru. Escola Paulista de Medicina. 2015. Available at $<$ http://www2.unifesp.br/dis/servicos/nutri/ public/alimento/nutriente/id/09316> Accessed May 29, 2019.

ZEIST, AR; RESENDE, JTV. 2019. Strawberry breeding in Brazil: current momentum and perspectives. Horticultura Brasileira 37: 07-16.

ZHANG, N; SUN, Q; ZHANG, H, CAO, Y; WEEDA, S; REN, S; GUO, YD. 2015. Roles of melatonin in abiotic stress resistance in plants. Journal of Experimental Botany 66: 647-656. 